\title{
Implementasi RPOA-IUU di Kawasan Asia Tenggara
}

\author{
Mauly Dini Budiyanti \& Arfin Sudirman \\ Universitas Padjadjaran
}

\begin{abstract}
ABSTRAK
Asia Tenggara merupakan salah satu kawasan yang rentan akan tindakan Illegal, Unreported, Unregulated (IUU) Fishing. Masalah ini mempunyai karakteristik transnasional dimulai dari lokasi, pelaku serta bendera kapalnya. Pelaku dari tindakan IUU Fishing kebanyakan berasal dari negara-negara tetangga. Oleh karena itu, penanganan masalah ini memerlukan peran serta komitmen bersama. Salah satu langkah kawasan dalam menangani masalah ini adalah melalui Regional Plan of Action to Promote Responsible Fishing Practices including Combating IUU Fishing (RPOA-IUU) yang didalamnya memuat berbagai rekomendasi tindakan untuk mendukung penangkapan ikan yang bertanggung jawab dan berkelanjutan. Tulisan ini akan membahas mengenai kapabilitas dan kemauan implementasi RPOA-IUU oleh lima negara anggotanya, yakni Indonesia, Malaysia, Filipina, Thailand dan Vietnam, juga mengenai implementation gap yang muncul ketika implementasi aktual setiap negara tidak sesuai dengan apa yang telah disepakati. Tulisan ini menggunakan metode kualitatif deskriptif dalam penjelasan implementasi dari tiap negara serta menggunakan teori implementasi rezim untuk menganalisis implementation gap pada RPOA-IUU.
\end{abstract}

Kata-kata kunci: Implementasi, implementation gap, RPOA-IUU

Southeast Asia is one of the areas vulnerable to IUU Fishing. This problem has transnational characteristics starting from location, perpetrator and flag of the ship. The perpetrators of IUU Fishing mostly come from neighboring countries. Therefore, handling this problem requires a joint role and commitment. One of the regional measures in dealing this problem is through Regional Plan of Action to Promote Responsible Fishing Practices including Combating IUU Fishing (RPOA-IUU) which contains various recommendations for actions to promote responsible and sustainable fishing. This paper will discuss the capabilities and willingness of RPOA-IUU implementation by its five member countries, Indonesia, Malaysia, Philippines, Thailand and Vietnam, as well as the implementation gap that arises when the actual implementation of each country is not in accordance with what has been agreed. This paper uses descriptive qualitative methods in explaining the implementation of the RPOA IUU by each country and also uses the regime implementation theory to analyze the implementation gap in the RPOA-IUU.

Keywords: implementation, implementation gap, RPOA-IUU 
Illegal, Unreported, Unregulated (IUU) Fishing merupakan masalah global yang tidak dapat ditangani oleh satu negara saja. Berdasarkan data dari FAO, IUU Fishing diestimasikan mewakili 15\% sampai dengan 30\% jumlah tangkapan ikan global tahunan. Tingginya tingkat IUU Fishing tersebut dikarenakan beberapa faktor seperti tingginya permintaan dalam sektor perikanan, resiko yang diperoleh bersifat jauh lebih minim dibandingkan dengan keuntungan yang didapatkan, tidak memerlukan keahlian nelayan tertentu, serta sulitnya membedakan hasil tangkapan ikan secara legal maupun illegal (National Intelligence Council 2016). Lebih lanjut, FAO menyebutkan 40,3 juta orang di dunia terlibat dalam bidang penangkapan ikan sementara sekitar 4,3 milyar orang bergantung pada stok perikanan sebagai sumber protein mereka (FAO 2018). Seiring pertumbuhan jumlah populasi serta standar kehidupan manusia, permintaan perikanan global akan terus meningkat. Di sisi lain, adanya tindakan IUU Fishing berpengaruh pada stok perikanan yang semakin menurun (National Intelligence Council 2016).

Mengingat karakteristik IUU Fishing yang bersifat transnasional, dan sebagai kawasan yang secara geografis terdiri dari wilayah maritim yang luas, Asia Tenggara menjadi salah satu kawasan yang rentan akan tindakan terjadinya IUU Fishing (Asia-Pacific Economic Cooperation; Fisheries Working Group 2008). Berdasar hal tersebut diperlukannya implementasi RPOA-IUU oleh lima negara pendukungnya, yakni Indonesia, Malaysia, Filipina, Thailand, dan Vietnam. Adapun tulisan ini membahas lebih lanjut bagaimana implementasi RPOA-IUU Fishing yang dilakukan oleh negara-negara Asia Tenggara tersebut, termasuk di dalamnya adalah implementation gap yang muncul dalam prosesnya.

\section{RPOA-IUU sebagai Rezim Internasional}

Sebagai sebuah upaya kawasan dalam memberantas tindakan IUU Fishing, dalam tulisan ini RPOA-IUU dianggap sebagai sebuah rezim IUU Fishing. Terdapat berbagai pengertian mengenai rezim internasional, yang salah satunya dipaparkan oleh Stephen hasner (1982) sebagai prinsip, norma, aturan, dan prosedur pembuatan keputusan baik secara eksplisit dan implisit yang berkaitan dengan ekspektasi dan harapan aktor pada suatu area dalam hubungan internasional. Dalam implementasi rezim terkadang muncul celah antara hasil secara nyata dengan ekspektasi yang diharapkan, hal ini biasa disebut dengan implementation gap (Farber 2016). Implementation gap terjadi karena negara anggota tidak dapat 
menunaikan kewajiban internasional setelah menyatakan setuju terhadap komitmen tertentu. Bagi negara-negara berkembang, political will negara dalam menandatangani suatu persetujuan internasional berada dalam kondisi puncak sedangkan political will negara tersebut justru kurang terlihat dalam skala nasional ketika mereka gagal dalam mengubah kewajiban internasional menjadi kebijakan nasional, undang-undang, atau penyediaan dana untuk implementasi dan penegakan program (Hinds 2003).

RPOA-IUU merupakan sebuah upaya pemberantasan IUU Fishing yang diinisiasi oleh Indonesia dan Australia serta ditandatangani oleh delegasi yang mewakili bidang perikanan dari sebelas negara anggota, yakni Australia, Brunei, Filipina, Indonesia, Kamboja, Malaysia, Papua Nugini, Singapura, Timor Leste, Thailand dan Vietnam. Terdapat sepuluh rencana tindakan atau yang kemudian disebut sebagai core element dalam RPOA-IUU tersebut, yakni: (1) Situasi sumber daya serta pengawasan terkini di kawasan; (2) Implementasi instrumen internasional dan regional; (3) Peran dari organisasi regional dan multilateral; (4) Tanggung jawab negara pantai; (5) Tanggung jawab negara bendera; (6) Port State Measures (PSM); (7) Regional market measures; (8) Pembentukan kapasitas regional; (9) Penguatan Management Control System (MCS); (10) Perpindahan di laut (transshipment at sea) (RPOA-IUU 2019). Dari sepuluh poin tersebut, terdapat lima poin prioritas yang disebutkan pada pertemuan RPOA-IUU Agustus 2007 di Malaysia, diidentifikasikan lima tindakan prioritas yang diantaranya adalah penguatan MCS, situasi sumber daya dan pengelolaan terkini di kawasan, pembentukan kapasitas regional, kewajiban negara pantai serta PSM (SEAFDEC 2010).

Dalam implementasinya, terdapat prinsip dan norma dalam RPOAIUU yang perlu ditaati oleh negara anggotanya. Prinsip dalam RPOA-IUU adalah voluntary non-binding. Prinsip ini menekankan adanya peran aktif secara sukarela dari masing-masing negara dalam memberantas serta mengatasi IUU Fishing (Baskoro 2019). Sementara itu, norma dalam RPOA-IUU ini adalah pengelolaan sumber daya laut kawasan yang berkelanjutan serta praktik penangkapan ikan yang bertanggung jawab. Dengan demikian, setiap aturan yang terdapat di dalam RPOA-IUU harus sesuai dan mendukung prinsip dan norma tersebut. Dalam penelitian ini, dari sepuluh poin yang dibahas dalam RPOA-IUU, disebutkan mengenai lima poin priotitas yang telah dibahas sebelumnya. Salah satu aturan yang terdapat pada lima poin prioritas dari RPOA-IUU tersebut diantaranya yakni mengenai penguatan MCS. Tindakan yang meliputi penguatan MCS diantaranya adalah pemasangan 
perangkat kontrol lalu lintas di laut Variable Message Sign (VMS) pada kapal berlisensi, aturan mengenai praktik penangkapan ikan, patroli perikanan, serta inspeksi kapal. Selanjutnya mengenai situasi sumber daya dan pengelolaan terkini di kawasan menyebutkan bahwa negara di kawasan harus bekerja bersama dalam menyusun gambaran luas mengenai penangkapan perikanan artisanal dan industri, status stok ikan saat ini, serta arus perdagangan dan pasar. Adapun mengenai pembangunan kapasitas regional, negara diharuskan untuk meningkatkan operasi dan implementasi yang kompeten secara teknis. Lalu mengenai tanggung jawab negara pantai, setiap negara harus mengimplementasikan NPOA sebagai upaya mempercepat pemberantasan over-capacity dan illegal fishing di kawasannya. Terakhir mengenai PSM, negara harus mempertimbangkan pengadopsian langkah negara pelabuhan berdasakan FAO 'Model Scheme on Port State Measures to Combat IUU Fishing' (PSMA) (RPOA-IUU 2019). Pada dasarnya, penjabaran poin diatas setidaknya menjelaskan mengenai aturanaturan yang terdapat dalam rezim RPOA-IUU mengenai tindakan yang seharusnya dilakukan oleh negara untuk menangani masalah IUU Fishing.

\section{Implementasi RPOA-IUU oleh Negara Anggota}

Indonesia menyadari bahwa IUU Fishing bukan hanya masalah pengelolaan perikanan namun dapat berasosiasi dengan tindakan kriminal melalui rantai penangkapan ikan dan Transnational Organized Crime (TOC), sehingga hal ini membuat Indonesia menjadi negara yang paling aktif dalam mengangkat isu IUU Fishing (RPOA-IUU 2017). Pada tahun 2012, Indonesia mengimplementasikan salah satu tanggung jawab negara pantai dengan mempublikasikan NPOA-IUU (2012-2016). Sebagai pembuka, NPOA-IUU Indonesia menjelaskan mengenai kondisi penangkapan ikan di Indonesiayang mencakup wilayah penangkapan dan syarat penangkapan ikan di Indonsia yang meliputi harus adanya SIPI (Surat Izin Penangkapan Ikan), SIKPI (Surat Izin Kapal Penangkap Ikan), SIUP (Surat Izin Usaha Perikanan), dan pengajuan izin penangkapan yang ditujukan pada Dirjen Kementerian Kelautan dan Perikanan bagi kapal >30 GT, pemerintah provinsi untuk kapal 10 s.d. 30 GT, serta pemerintah kota/kabupaten untuk kapal 5 s.d. 10 GT (Indonesia NPOA-IUU 2012).

Implementasi MCS perikanan melibatkan kordinasi dari berbagai agensi seperti Kementerian Kelautan dan Perikanan (KKP), TNI-AL, 
Polisi Air, Bakamla serta Direkotorat Jenderal Transportasi Laut (HUBLA) Kementerian Perhubungan. Aktivitas surveillance serta penegakan hukum dilakukan dengan keterlibatan Kementerian Kelautan dan Perikanan, TNI-AL, Polair, Bakamla, Kejaksaan Agung, serta Pengacara Umum dengan perannya masing-masing(Indonesia NPOA-IUU 2012). Mengenai controlling, legislasi perikanan Indonesia disebutkan telah menggunakan konsep lingkungan dan pengelolaan perikanan berkelanjutan sesuai dengan norma dari RPOA-IUU. Di dalamnya juga telah mensyaratkan adanya registrasi kapal yang akan melakukan penangkapan serta lisensi umum bagi aktivitas penangkapan ikan komersil (Australian National Centre for Ocean Resource and Security 2010). Tentunya, pengimplementasian MCS tersebut mendapat penilaian baik dari IUU Risk Intelligence.

Pada tahun 2017, Indonesia telah mengadopsi FAO Port State Measures Agreement (PSMA) (RPOA-IUU 2017). Untuk mendukung pengimplementasian PSM yang efektif, Indonesia merancang lima pelabuhan perikanan, yakni pelabuhan Nizam Zachman, Belawan, Bitung, Pelabuhan Ratu, dan Ambon, serta program pelatihan terbaru bagi pegawai KKP (BOBLME, 2015; Indonesia NPOA-IUU 2012). Lain halnya mengenai pembangunan kapasitas regional, pada Coordination Committee Meeting 2018 Indonesia menyarankan INTERPOL untuk melakukan identifikasi pembangunan kapasitas bagi negara-negara RPOA-IUU. Selain itu, Indonesia juga mengajak negara-negara anggota lainnya untuk bekerja sama dengan INTERPOL (RPOA-IUU 2018). Dalam hal ini terlihat Indonesia mempunyai kepentingan yang tinggi untuk menjaga wilayah maritimnya termasuk dari tindakan IUU Fishing. Indonesia mampu menyelaraskan dan menerapkan hal yang telah disepakati dalam RPOA-IUU terhadap tindakan serta hukum domestik negaranya. Maka dari itu, Indonesia disebut sebagai pihak yang selalu konsisten dalam membahas maupun mengangkat masalah IUU Fishing dalam berbagai forum internasional dan regional.

Sama halnya dengan Indonesia, adanya IUU Fishing menjadi masalah serius yang berdampak pada kehidupan ekonomi dan sosial para nelayan juga pada industri perikanan Malaysia. Selain itu, illegal fishing yang dilakukan oleh kapal asing memberikan ancaman keamanan bagi negara serta kompetisi tidak sehat bagi nelayan lokal. Malaysia menyadari bahwa tindakan IUU Fishing ini merupakan masalah yang serius dimana penanganan serta pemberantasannya harus dilakukan secara komprehensif dan integratif baik dalam skala nasional, regional maupun internasional (Malaysia NPOAIUU 2013). Berdasarkan hal tersebut, pengelolaan penangkapan di Malaysia dibagi ke dalam empat sistem zonasi berdasarkan jarak 
serta muatan kapal. Disebutkan juga bahwa setiap kapal serta segala jenis penangkapan ikan di Malaysia harus mempunyai lisensi kapal serta alat tangkap ikan yang sah (Malaysia NPOA-IUU 2013). Hal ini berarti mencakup dua poin dari implementasi IUU Fishing mengenai tanggung jawab negara pantai dan informasi sumber daya perikanan terkini. Aktivitas monitoring termasuk di dalamnya penggunaan VMS juga dilakukan meski tidak banyak kapal yang memilikinya (Ganapthiraju 2017). Adapun aktivitas controlling meliputi lisensi dan pendaftaran kapal penangkap ikan, persyaratan penandaan kapal, pengawasan pendaratan, pengawasan dan pelarangan terhadap metode penangkapan ikan, pengawasan transshipment, pengeluaran ID perikanan serta pengembangan zona perikanan dan Marine Prohibited Area (MPA) atau kawasan laut terlarang seperti misalnya wilayah konservasi (Malaysia NPOA-IUU 2013). Lebih lanjut, aktivitas surveillance dilakukan oleh pemerintah Malaysia dengan melakukan boarding (memasuki kapal yang dicurigai) dan inspeksi yang dilakukan oleh petugas perikanan serta otoritas penegakan hukum di laut lainnya. Aktivitas surveillance ini dilakukan baik di udara maupun permukaan (Malaysia NPOA-IUU 2013). Namun demikian, kapasitas MCS Malaysia terbilang lemah karena kondisi kapal yang buruk dan sudah tua. Kurangnya kordinasi antar lembaga seperti MMEA dengan agensi penegakan lainnya pun merupakan salah satu hambatan MCS di Malaysia. Oleh karena itu, IUU Risk Intelligence menyatakan bahwa MCS perikanan Malaysia ini lemah (Ganapthiraju 2017).

Sedangkan bagi Filipina, tindakan IUU Fishing ini bertentangan dengan prinsip serta tujuan dari Fisheries Code untuk ketahanan pangan serta tindakan pengelolaan ikan yang bertanggung jawab. Pada tahun 2013, Filipina mempublikasikan NPOA-IUU yang pada bagian awal dijelaskan mengenai kondisi penangkapan ikan di Filipina (Philippines NPOA-IUU 2013). Filipina menerapkan sistem MCS perikanan yang melibatkan beberapa agensi. Monitoring dilakukan oleh berbagai lembaga di Filipina seperti BFAR (Biro Perikanan di Filipina), Fisheries and Aquatic Resource Management Councils (FARMCs), serta akademisi. Tindakan ini meliputi penerapan alat monitoring seperti sistem lisensi serta sistem laporan penangkapan ikan, proyek penilaian sumber daya dan sistem informasi perikanan (Philippines NPOA-IUU 2013). Sementara itu, upaya controlling dalam NPOA-IUU Filipina meliputi hukum serta kerangka regulasi perikanan. Tindakan tersebut melibatkan BFAR, Lembaga Perwakilan, Senat dan Pejabat Presiden. Dalam hal ini, aktivitas surveillance Filipina dapat dilakukan di darat, laut maupun udara. 
Lebihlanjut, implementasi sistem MCSdi Filipina didesentralisasikan kepada Pejabat Perikanan Regional (Philippines NPOA-IUU 2013). Sejauh ini, kapasitas MCS Filipina dinilai cukup bagus oleh IUU Risk Intelligence meskipun kapasitas penegakan nasional Filipina masih dinilai belum cukup untuk melakukan pengawasan pada wilayah Zona Ekonomi Eksklusif (ZEE) Filipina yang luas. Ditambah dengan Flipina yang sempat menerima kartu kuning akibat melakukan perubahan legislasi pada masalah IUU Fishing tepatnya pada tahun 2014 (espejo 2015). Meskipun begitu Filipina dianggap aktif dalam melakukan patroli bersama di lautan dengan Indonesia dan Malaysia. Tindakan patroli bersama ini sering dilakukan di Laut Sulu yang di dalamnya mencakup ZEE Filipina, Indonesia, dan Malaysia. Selain itu, Filipina mendukung pertukaran informasi dengan negara tetangga untuk mengawasi warga negara Filipina yang terlibat dalam IUU Fishing (Philippines NPOA-IUU 2013). Melalui pemaparan tersebut dapat diketahui bahwa political will Filipina pada skala internasional, khususnya dalam partisipasi pada pertemuan tahunan RPOA-IUU ini terbilang kurang. Padahal dalam forum regional lainnya yang membahas IUU Fishing, Filipina terlihat mendukung tindakan tersebut (Astuti 2019).

Sebagaimana Malaysia dan Filipina, Thailand juga menyadari bahwa IUU Fishing merupakan ancaman yang serius bagi sumber daya perikanan nasional dan internasional sehingga membutuhkan tindakan nasional, regional, serta global yang konkret untuk mengatasi masalah ini. Illegal fishing merupakan prioritas tugas keamanan maritim ketiga setelah human trafficking dan perdagangan narkoba di Thailand (Ganapthiraju 2017). Thailand juga menyatakan bahwa tindakan IUU Fishing berasosiasi dengan kejahatan transnasional maritim lintas batas (Thailand NPOA-IUU 2015). Melalui pernyataan tersebut dapat diketahui bahwa Thailand meyakini bahwa IUU Fishing memerlukan tindakan pemberantasan yang konkret secara nasional, regional, dan internasional. Hukum mengenai perikanan di Thailand sendiri diatur dalam Fisheries Act 1947, yang diamandemen pada tahun 2015 (BOBLME 2015). NPOA-IUU Thailand telah memuat rencana mengenai alokasi data untuk mendukung pelatihan yang berkaitan dengan sektor MCS. Monitoring dilakukan oleh Departement of Fisheries dan sejumlah pelabuhan serta lokasi pendaratan di seluruh wilayah Thailand. Setiap kapal yang melakukan penangkapan di Perairan Thailand diharuskan menggunakan fishing logbook sebagai syarat penyerahan laporan penangkapan ikan yang efektif dan terlacak (Thailand NPOA-IUU 2015). Dalam hal ini controling terdiri dari legislasi serta regulasi mengenai apa yang legal dan illegal dalam penangkapan ikan di Thailand. Tindakan ini dilakukan 
oleh Minister of Agriculture and Cooperatives sedangkan aturan dan pemberitahuan yang berkaitan dengan aktivitas penangkapan diatur oleh Dirgen of Department of Fisheries (Thailand NPOAIUU 2015). Kegiatan surveillance dilakukan oleh beberapa badan yang terotoritasi, yang berarti tindakan patrolinya dilakukan oleh Angkatan Laut Thailand. Berdasar hal ini kapasitas MCS Thailand dinilai cukup efektif pada beberapa yurisdiksi (Ganapthiraju 2017). Melalui pemaparan diatas, dapat diketahui bahwa Thailand dapat mengimplementasikan rekomendasi tindakan serta Political will Thailand dalam memberantas tindakan IUU Fishing terlihat lebih kuat. Meski dalam hal ini, RPOA-IUU harus mendapat peringatan dari Uni Eropa sebelumnya karena ditemukannya aktivitas yang tidak sesuai norma untuk penangkapan ikan yang bertanggung jawab dan berkelanjutan. Artinya, dalam hal ini Thailand dapat melakukan upaya yang serius meski harus didahului dengan tekanan dari negara yang memiliki power lebih atas dasar penyelewengan yang terjadi sebelumnya.

Berbeda dengan negara anggota sebelumnya, Vietnam tidak menjadikan illegal fishing sebagai prioritas tugas keamanan maritim negaranya, padahal perikanan di Vietnam berkontribusi sebesar 4\% terhadap GDP (Ganapthiraju 2017). Hal ini menunjukan bahwa kebijakan nasional Vietnam lebih mengacu pada tindakan untuk meningkatkan produksi perikanan dibandingkan dengan konservasi ketersediaan perikanan. Bahkan Vietnam belum membuat NPOAIUU atau rencana tindakan lain yang sejalan dengan rekomendasi internasional. Hal ini berarti bahwa Vietnam belum memaparkan kondisi penangkapan ikan terkini negaranya yang biasanya tercantum dalam NPOA-IUU. Oleh karena itu, Vietnam belum mengimplementasikan dua rekomendasi tindakan mengenai tanggung jawab negara pantai dan situasi penangkapan ikan terkini.

Dalam konteks ini, aktivitas MCS di Vietnam sejatinya telah dilakukan oleh Vietnam Coastguard dan dibantu oleh Border Guard (BOBLME 2015). Namun, dapat dikatakan bahwa infrastruktur surveillance Vietnam masih kurang. Vietnam hanya memiliki 38 kapal patroli yang hanya efektif pada beberapa wilayah dan tidak efektif sama sekali di wilayah lepas pantai. Kapasitas pengawasan udara untuk mengawasi kapal asing yang beroperasi di ZEE Vietnam pun dinilai parsial dan kurang mumpuni. Selain itu, kegiatan surveillance dilakukan satu bulan sekali dengan jumlah perjalanan yang bervariasi. Begitu pula dengan kegiatan monitoring yang hanya dilakukan untuk kepentingan biologi (Ganapthiraju 2017). Maka dari itu, MCS di Vietnam dinilai tidak efektif serta kapasitas penegakannya pun dinyatakan lemah bahkan tidak ada sama sekali 
(BOBLME 2015). Mengenai controlling, legislasi perikanan Vietnam diatur dalam Fisheries Law 2017 yang merupakan amandemen dari Fisheries Law 2003. Legislasi perikanan yang baru menempatkan sanksi bagi pelaku IUU Fishing serta mengharuskan pemasangan VMS dalam kapal penangkap ikan (RPOA-IUU 2018). Tinjauan RPOA-IUU menyebutkan bahwa legislasi perikanan Vietnam telah berbasis lingkungan, menerapkan pengelolaan perikanan berkelanjutan, memperkenalkan rencana pengelolaan, persyaratan registrasi kapal serta mengimplementasikan lisensi umum untuk aktivitas kapal komersil (Australian National Centre for Ocean Resource and Security 2010). Dalam legislasinya, Vietnam dapat dikatakan telah mencerminkan pandangan yang mendukung tindakan penangkapan ikan yang bertanggung jawab dan berkelanjutan. Sejauh ini, Vietnam baru menyatakan tertarik untuk menerima bantuan yang berkaitan dengan pertimbangan ratifikasi serta implementasi PSMA (RPOA-IUU 2017).

Terlepas dari berbagai kekurangan yang ada, Vietnam menyebutkan beberapa kemajuan sistem perikanannya dalam Committee Cordination Meeting. Hal ini dibuktikan pada tahun 2018, Vietnam menyatakan telah melakukan survey serta riset sumber daya perikanan dan laut bersama Tiongkok. Selain itu, Vietnam juga telah membentuk panggilan bersama dengan Filipina dan Tiongkok untuk berbagi pengalaman dan informasi mengenai perikanan. Di samping itu, Vietnam juga menyatakan akan segera melakukan tindakan tersebut bersama negara lainnya seperti Indonesia, Kamboja dan Thailand (RPOA-IUU 2018).

Meskipun Vietnam kerap berpartisipasi dalam Coordination Committee Meeting, legislasinya telah berbasis lingkungan, sesuai dengan pengelolaan perikanan berkelanjutan dan memperkenalkan rencana pengelolaan, hal tersebut tidak menjadi tolok ukur bahwa tindakan yang dilakukan Vietnam akan mengarah pada tindakan penangkapan ikan yang berkelanjutan dan bertanggung jawab. Dapat diketahui bahwa Vietnam tidak mengimplementasikan beberapa rekomendasi tindakan dari RPOA-IUU seperti tanggung jawab negara pantai, masih mempertimbangkan untuk meratifikasi PSMA, serta MCS Vietnam lemah bahkan tidak ada. Hal ini dapat didasari karena Vietnam lebih mengutamakan pertumbuhan sektor perikanan yang ambisius.Vietnam lebih fokus pada tindakan dan kebijakan yang berorientasi pada pendapatan tanpa memperhatikan kepatuhan terhadap peraturan yang telah disepakati. Maka dari itu, meski political will Vietnam dalam skala internasional mungkin tinggi namun, dalam skala nasional political will Vietnam dalam RPOA-IUU kalah dengan political will Vietnam untuk 
memprioritaskan tindakan yang dapat menguntungkan produksi serta panen perikanan dengan segala cara.

\section{Implementation Gap dalam RPOA-IUU}

Berdasarkan prinsip RPOA-IUU setiap negara diharapkan dapat sukarela berperan aktif dalam menangani masalah IUU Fishing. Pada pelaksanaannya, masing-masing negara mempunyai peran aktif yang berbeda sesuai dengan kapasitas dan kapabilitas negaranya. Dalam pengimplementasian aturan pada RPOA-IUU pada dasarnya masih terdapat gap antara hal yang tertulis dengan implementasi aktual dari masing-masing negara. Pada penguatan MCS, Indonesia dan Filipina mempunyai kapasitas MCS yang cukup baik. Hal ini dibutuhkan oleh kedua negara mengingat ZEE keduanya sangat luas sebagai negara kepulauan. Selanjutnya, Thailand mempunyai kapasitas MCS yang cukup untuk luas ZEE negaranya. Sedangkan Malaysia dan Vietnam mempunyai kapasitas MCS yang lemah karena infrastruktur MCS yang tertinggal.

Pada situasi sumber daya perikanan terkini di kawasan, masingmasing negara telah mencantumkan gambaran umum mengenai penangkapan ikan negaranya dalam NPOA-IUU. Diantara lima negara yang dibahas, hanya Vietnam yang belum mengimplementasikan tanggung jawab negara pantai dengan mempublikasikan NPOA-IUU. Maka dari itu, Vietnam juga menjadi satu-satunya negara yang belum menyertakan gambaran situasi perikanan di negaranya. Dalam pengimplementasian tanggung jawab negara pantai, Indonesia dan Malaysia senantiasa melakukan mempublikasi NPOA-IUU tanpa adanya dorongan dari pihak lain. Sedangkan Thailand dan Filipina, keduanya baru mempublikasikan NPOA-IUU ketika mendapat peringatan kartu kuning dari Uni Eropa.

Sementara itu, dalam pembangunan kapasitas regional, masingmasing negara mempunyai peran yang baik untuk meningkatkan kapasitasnya. Malaysia dan Filipina melakukan patroli bersama untuk meningkatkan stabilitas di kawasan. Vietnam melakukan riset perikanan dengan Tiongkok dan saling berbagi informasi serta pengalaman dengan Filipina. Begitu juga Thailand sebagai markas utama riset perikanan kawasan, SEAFDEC. Serta Indonesia melalui permintaan bantuan pembangunan kapasitas negara-negara RPOAIUU terhadap INTERPOL. Prioritas aturan yang terakhir dalam hal ini yakni mengenai pengadopasian PSM. Poin ini merupakan salah satu poin yang selalu dibahas dalam setiap Coordination 
Committee Meeting. Dengan kata lain, dapat diketahui bahwa pengimplementasian PSM ini dianggap penting dalam RPOA-IUU. Dari lima negara, Indonesia dan Thailand telah meratifikasi FAO PSMA. Sebagai implementasi tambahan, Indonesia telah merancang lima pelabuhan perikanan sedangkan Thailand membuat sistem PIPO untuk pengecekan kapal yang masuk. Malaysia dan Vietnam masih dalam pertimbangan ratifikasi, sedangkan Filipina belum meratifikasi PSMA karena beranggap bahwa ratifikasi ini dapat meningkatkan transshipment at sea.

Selanjutnya, mengenai prosedur kolaborasi dalam RPOA-IUU yang dilakukan melalui pertemuan tiap tahun dalam Coordination Committee Meeting, implementasi ini dapat dilihat dari komitmen masing-masing perwakilan negara dalam menghadiri pertemuan ini. Indonesia, Thailand dan Vietnam merupakan negara yang belum pernah absen dalam pertemuan ini. Selain itu, Indonesia juga merupakan negara yang paling banyak membawa perwakilan dari negaranya (di luar staff sekretariat). Selanjutnya Malaysia pernah sekali absen dalam pertemuan ini, sedangkan Filipina merupakan negara yang sangat jarang hadir dalam pertemuan ini.

Melalui pemaparan tersebut dapat diketahui masih terdapat gap dalam implementasi RPOA-IUU oleh negara anggotanya. Disamping akibat perbedaan kapasitas serta kapabilitas setiap negara, gap juga diakibatkan oleh beberapa alasan lain seperti korupsi dan political will setiap negara. Bagi Thailand, pengimplementasian aturan dalam RPOA-IUU dilakukan ketika Thailand mendapat peringatan dari Uni Eropa. Political will Thailand dalam mengubah sistem serta legislasi perikanan di negaranya menjadi tinggi ketika negaranya terancam tidak dapat mengekspor hasil tangkapan ikannya ke negara-negara Uni Eropa. Setelah peringatan tersebut dicabut, kondisi pengelolaan perikanan di Thailand kembali pada keadaan semula karena budaya korupsi, lembaga yang apatis serta tidak adanya 'tekanan' yang dihindari. Dengan kata lain, dalam hal ini diperlukan 'sanksi' serta pihak yang mempunyai power yang lebih besar untuk membuat setiap aturan dapat diimplementasikan dengan baik.

Selanjutnya,politicalwillVietnam dinilaikurang dalamimplementasi RPOA-IUU adalah karena Vietnam fokus pada pertumbuhan sektor perikanan yang ambisius. Kapal-kapal Vietnam tidak hanya menangkap ikan di ZEE Vietnam saja namun juga di ZEE negara lain serta di laut bebas tanpa izin. Dalam hal ini, Vietnam lebih fokus pada kebijakan yang menguntungkan pendapatan negara Vietnam tanpa memperhatikan komitmen yang telah dibuat. Sebaliknya, political will negara akan lebih kuat dalam implementasi RPOA-IUU ketika 
negara tersebut merupakan negara yang paling dirugikan akibat tindakan IUU Fishing ini, seperti halnya Indonesia. Pemerintah Indonesia melakukan upaya yang konsisten dalam mengangkat IUU Fishing dalam berbagai forum internasional dan regional. Selain itu, Indonesia juga menjadi negara yang penegakan hukum IUU Fishingnya lebih 'keras' dibanding dengan negara anggota yang lain. Hal ini menunjukan komitmen negara Indonesia untuk memberantas tindakan IUU Fishing.

Berbeda dengan yang lain, political will skala internasional Filipina justru lebih rendah disbanding skala nasionalnya. Hal ini dapat dilihat dari partisipasi Filipina pada pertemuan tahunan RPOA-IUU yang terbilang kurang. Padahal dalam forum regional lainnya yang membahas IUU Fishing, Filipina terlihat mendukung tindakan tersebut. Sebaliknya, political will Filipina terbilang baik karena mampu mengimplementasikan berbagai rekomendasi tindakan yang sesuai dengan norma dan aturan dalam RPOA-IUU. Bahkan Filipina mampu meyakinkan UE bahwa negaranya akan patuh terhadap instrumen IUU Fishing internasional. Sedangkan Malaysia, tidak begitu menunjukan posisi negaranya mengenai dukungan atau perlawanan terhadap pembahasan IUU Fishing. Dalam tindakannya, Malaysia senantiasa berupaya melakukan implementasi tanpa adanya tekanan dari pihak lain baik dalam skala nasional maupun internasional.

\section{Kesimpulan}

Implementasi rezim RPOA-IUU yang dilakukan oleh Indonesia, Malaysia, Filipina, Thailand dan Vietnam bergantung pada kapasitas serta kapabilitas setiap negara. Selain itu, implementasi juga dilakukan berdasarkan political will masing-masing negara dalam menangani masalah IUU Fishing. Bagi negara yang dirugikan akibat tindakan IUU Fishing seperti Indonesia, implementasi dilakukan dengan cukup baik. Sedangkan bagi negara yang lebih mementingkan masalah pendapatan dari sektor perikanan tanpa memperhatikan aktivitas penangkapan ikan yang bertanggung jawab seperti Thailand dan Vietnam, implementasi tidak dilakukan dengan baik. Untuk membuat negara melakukan implementasi RPOA-IUU dengan baik, diperlukan sanksi berupa peringatan pemberhentian ekspor hasil tangkapan ikan oleh negara-negara pasar. Dari penelitian ini, dapat dilihat masih terdapatnya implementation gap dalam pengimplementasian RPOA-IUU. Beberapa alasan terdapatnya gap dalam pengimplementasian tersebut adalah political will, korupsi, 
Mauly Dini Budiyanti dan Arfin Sudirman

serta lembaga yang apatis. Bentuk implementation gap yang paling konkret dapat dilihat dari masih maraknya IUU Fishing di kawasan yang dilakukan oleh kapal dari negara anggota RPOA-IUU. 


\section{Daftar Pustaka}

\section{Buku}

FAO, 2018. The State of World Fisheries and Aquaculture 2018 Meeting the sustainable development goals. Rome.

\section{Jurnal dan Jurnal Daring}

Farber, D. A., 2016. The Implementation Gap in Environmental Law. Journal of Korean Law Vol. 16, 3-32.

Haas, E. B., 1980. Why Collaborate? Issue-Linkage and International Regimes. World Politics Volume 32 Issue 03, 358.

Hinds, L., 2003. Oceans governance and the implementation gap. Marine Policy 27, 349-356.

Jackson, W., \& Bührsb, T, 2015. International Environmental Regimes:Understanding Institutional and Ecological Effectiveness. Journal of International Wildlife Law \& Policy ,18:1, 63-83.

Krasner, S., 1982. Structural Causes and Regime Consequences: Regimes as Intervening Variables. International Organization Vol. 36 No. 2, 185-205.

\section{Laporan dan Working Paper}

Asia-Pacific Economic Cooperation; Fisheries Working Group. 2008. Assessment of Impacts of Illegal, Unreported and Unregulated (IUU) Fishing in the Asia-Pacific. Singapore: APEC Secretariat.

BOBLME, 2015. Review of impacts of Illegal, Unreported and Unregulated fishing on developing countries in Asia. BOBLME-2015-Governance-15.

Ganapathiraju, P., 2017. Thailand - Country Report, 8 pages, In: Policing the Open Seas: Global Assessment of Fisheries Monitoring Control and Surveillance in 84 Countries. Canada: IUU Risk Intelligence - Policy Report No. 1.

Ganapathiraju, P., 2017. Vietnam- Country Report, 8 pages, In: 
Policing the Open Seas: Global Assessment of Fisheries Monitoring Control and Surveillance in 84 Countries. Canada: IUU Risk Intelligence - Policy Report No. 1.

Ganapthiraju, P., 2017. Malaysia-Country Report, 6 pages, In: Policing the Open Seas: Global Assessment of Fisheries Monitoring Control and Surveillance in 84 Countries. Canada : IUU Risk Intelligence - Policy Report No. 1 .

SEAFDEC, 2010. Report of the Expert Consultation on Managing Fishing Capacity to Combat IUU Fishing in Southeast Asia, Bangkok, Thailand, 15-17 September 2010. Bangkok: Southeast Asian Fisheries Development Center.

\section{Artikel Daring}

Australian National Centre for Ocean Resource and Security. 2010. Model Fisheries Legslation [online]. dalam: http://www. rpoaiuu.org/model-fisheries-legislation/Asean Secretariat. 2016 [diakses 24 Juni 2019].

Espejo, E., 2015, April 26. EU removes Philippines' illegal fishing 'yellow card' [online]. dalam: https://asiancorrespondent. com/2015/04/eu-removes-philippines-illegal-fishing-yellowcard/ [diakses 25 Juni 2019].

Indonesia NPOA-IUU, 2012. NPOA-IUU [online]. dalam: http:// www.rpoaiuu.org/wp-content/themes/modality/images/pdf/ npoa/Indonesia.pdf [diakses 23 Juni 2019].

Malaysia NPOA-IUU, 2013. Malaysia's NPOA-IUU [online]. dalam: https://www.dof.gov.my/dof2/resources/user_1/.../ Malaysia_NPOA_IUU.pdf [diakses 22 Juni 2019].

Philippines NPOA-IUU, 2013. NPOA-IUU [online]. dalam: http:// www.rpoaiuu.org/wp-content/themes/modality/images/pdf/ npoa/philippines2.pdf [diakses 20 Juni 2019].

RPOA-IUU, 2011. Summary Report The 4th Coordination Committee Meeting of the Regional Plan of Action to Promote Responsible Fishing Practices including Combating IUU Fishing in the Region [online]. dalam: http://www.rpoaiuu. org/wp-content/uploads/2017/01/4th-CCM-Report.pdf [diakses 19 Juni 2019]. 
RPOA-IUU, 2016. The 9th RPOA-IUU Coordination Committee. [online]. dalam: https://www.rpoaiuu.org/the-9th-rpoa-iuucoordination-committee/ [diakses 21 Juni 2019].

RPOA-IUU, 2017. Meeting Document: The 1oth Coordination Committee Meeting for the Regional Plan of Action to Promote Responsible Fishing Practices including Combating IUU Fishing in the Region (RPOA) [online]. dalam: https:// www.rpoaiuu.org/wp-content/uploads/2017/01/10th-CCMReport.pdf [diakses 23 Juni 2019].

RPOA-IUU, 2018. The 11th RPOA-IUU Coordination Committee Meeting [online]. dalam: https://www.rpoaiuu.org/the-11thrpoa-iuu-coordination-committee/ [diakses 24 Juni 2019].

RPOA-IUU, 2019. Core Element [online]. dalam: http://www. rpoaiuu.org/core-element/ [diakses 20 Juni 2019].

Thailand NPOA-IUU, (2015). Thailand NPOA-IUU [online]. dalam: https://www.iotc.org/sites/default/files/documents/ 2015/10/IOTC-2015-WPDCS11-INFo5_-_Thailand_NPOA_ IUU.pdf [diakses 18 Juni 2019].

\section{Wawancara}

Astuti, N. B., 2019, April 1. Implementasi Rezim RPOA-IUU di Kawasan Asia Tenggara. (M. D. Budiyanti, Interviewer).

Baskoro, A., 2019, Maret 18. Implementasi Rezim RPOA-IUU di Kawasan Asia Tenggara. (M. D. Budiyanti, Interviewer).

\section{Lain-lain}

National Intelligence Council, (2016, September 19). Global Implication of Illegal, Unreported, and Unregulated (IUU) Fishing . NIC Publications. 